\title{
On the Xylem Elements of the Pteridophyta.
}

\author{
BY \\ NELLIE BANCROFT, B.Sc., F.L.S. \\ Research Scholar in the University College of Nottingham.
}

With Plate LVI and three Figures in the Text.

A. Historical.

$7 \mathrm{HE}$ question regarding the nature of the xylem elements of Pteridophyta-whether they are vessels of ordinary type or of a special type, or whether they are tracheides -is one which has given rise to much discussion. The differences of opinion on this point are due to the difficulties attending the detection of the primary portions of the cell-wall in much altered tissues ; for upon the recognition of the presence of a pit-membrane, itself a part of the middle lamella of the primary cell-wall, depends the solution of the whole question. Dr. Fr. Halft (3) has recently given an excellent résumé of the views of the earlier investigators of this subject, pointing out that it was Sanio (11) who, in 1873 , caused general opinion to. turn in favour of the presence of the pit-closing membrane, at least in Phanerogams.

With regard to the Vascular Cryptogams, it was at first maintained that their xylem elements were true vessels, the presence of a pit-membrane being denied. De Bary (1), however, after the appearance of Sanio's work on the Scots Pine was led to investigate other forms, including Vascular Cryptogams. He, too, noted the pit-membrane, mentioning especially Pteris Aquilina, where it occurs in the side walls of the elements; and in 189I Strasburger (16) demonstrated that the Vascular Cryptogams in general possess pointed tracheides, dovetailing into one another and presenting no distinction between their end and side walls. At present only two exceptions to this general rule are known-the root of Nephrodium Filixmas and Pteris Aquilina having true vessels, since the end walls are perforated (Russow, 10).

In 1908 Prof. Gwynne-Vaughan (2) returned to the former theory of the vascular nature of the xylem elements of Ferns. His conclusions are based upon investigations suggested by the appearance of transverse sections of certain fossil forms referred to the Osmundaceae (Kidston and

[Annals of Botany, Vol. XXV. No, XCIX. July, 19ur.] 
Gwynne-Vaughan, 5 and 6). A transverse section of Osmundites skidegatensis, for example, shows, between the lignified parts of two adjacent elements, distinct splits not containing any trace of a 'middle substance'; and Gwynne-Vaughan compares with such a section one of the recent species, Osmunda cinnamomea, in which also he finds splits or spaces between the transverse bars of lignified substance.

Gwynne-Vaughan distinguishes two main types of 'vessel ', represented by the elements of Pteris Aquilina, and by those of Osmunda cinnamomea and Nephrodium Filix-mas respectively.

In Pteris Aquilina, as typical of the one group, he found that, although 'those parts of the primary wall that connect the opposite transverse bars of secondary thickening in the middle of the wall are here maintained intact even at maturity' (p. 52I), the pits on both end and side walls of the elements are true perforations. There is here, then, a free passage vertically and horizontally from element to element.

The second main type of 'vessel' includes some in which the pits occur in more than one series on each facet, and others in which there is only one series.

Osmunda cinnamomea-representative of the Osmundaceae as a whole-has typical multiseriate pitted elements. In these, according to Gwynne-Vaughan, the whole of the primary wall, including the middle lamella, disappears entirely, except at the angles of the elements and between the series of pits, where the wall remains solid. If this be the case, it follows that there must be a free passage vertically and horizontally as in Pteris, with an additional vertical passage in the spaces left by the disappearance of the primary wall.

Nephrodium Filix-mas possesses uniseriately pitted xylem elements, and in these the primary pectose layers and middle lamella are held by GwynneVaughan to disappear entirely, except at the angles. Here, therefore, there would seem to be still greater freedom for the movement of water, for not only must the elements be in communication vertically and horizontally, but the entire disappearance of the primary wall from between the transverse lignified bars must leave considerable spaces for the passage of water vertically between the elements, outside their actual cavities.

Gwynne-Vaughan thus concludes that the xylem elements of the Pteridophyta are mostly vessels, these being in certain cases, as typified by Osmunda and Nephrodium, of a special kind.

In I9I0 Halft's dissertation 'Die Schliesshaut der Hoftupfel im Xylem der Gefässkryptogamen' appeared, but it seems to have excited little attention in this country. The conclusions of this investigator entirely refute those of Gwynne-Vaughan, and support Strasburger's views as to the tracheidal nature of the xylem of Vascular Cryptogams (Halft, 3); for, by experiment and by examination of both longitudinal and transverse 
sections, he has been able to demonstrate that the pit-membranes are typically present in the end, as well as in the lateral walls of the elements. (In Pteris Aquilina the pit-membranes disappear from the cross walls, these being much less inclined to the lateral walls than is usual.) Halft further demonstrates that the primary wall remains between the bars of secondary thickening. The difference in the amount of cohesion of the bars gives rise to the presence or absence of the 'split ' between them, as seen in transverse section.

The results obtained by the writer lend strong support to the views put forward by Halft with regard to the tracheidal nature of the xylem elements of the majority, at least, of the Pteridophyta.

\section{B. Methods and Material.}

Unstained transverse sections of certain types, e.g. Gleichenia spp., Lygodium spp., and others, gave the impression that true empty spaces occurred between contiguous elements of the xylem, as Gwynne-Vaughan maintains. These sections when stained, however, failed to confirm the idea, the spaces never appearing clear, even under a magnification of 325 diameters. ${ }^{1}$ The appearance of Halft's paper suggested the reason for this and led to the following investigations.

\section{Microchemical Tests for Pectic Substances of the Primary Walls.}

Several chemical methods were employed in order to prove the presence of primary pectic substances separating the secondary lignified layers of the xylem elements. The first of these methods was that mentioned by Halft (3). This investigator treated transverse sections of Pteris Aquilina and Osmunda regalis with Schulze's maceration mixture (concentrated nitric acid and potassium chlorate), until the lignin of the secondary layers of thickening had disappeared, but apparently before the stronger lignification of the primary walls of the elements had been destroyed. It is a wellknown fact that lignified walls, after treatment with this maceration fluid, give the cellulose reaction. Halft therefore removed the residue of cellulose from his sections by means of strong sulphuric acid, and found that in the cases mentioned the primary walls and pit-membranes remained as a delicate network on the slide (cf. Strasburger, 17). In his description of the method he remarks that if the maceration fluid had not acted for a sufficient time the middle substances were much swollen, and that after treatment with $\mathrm{H}_{2} \mathrm{SO}_{4}$ they showed as a deep brown line, the secondary layers of thickening not disappearing entirely. If, on the other hand, the macerating medium had acted for too long a time the primary wall vanished along with the secondary layers on the addition of $\mathrm{H}_{2} \mathrm{SO}_{4}$.

\footnotetext{
1 Swift's I/6 objective. No. 3 , ocular.
} 


\section{Bancroft.-On the Xylem Elements of the Pteridophyta.}

Halft's method was followed in the treatment of sections of the petioles of Marattia elegans and $M$. laxa, but the results seemed to indicate that the mature tissues used were too strongly lignified for the maceration fluid to remove the lignin completely before the dissolution of the lamella took place. Other experiments, however, were decidedly satisfactory, sections of Selaginella Wildenovii, treated for a very short time with the maceration fluid and then transferred to strong $\mathrm{H}_{2} \mathrm{SO}_{4}$, giving the desired result. The primary membranes remained after the removal of the secondary layers, but at the corners of the cells small patches of lignified substance also remained, demonstrating that these were the most strongly lignified areas, and therefore the most resistant to the macerating fluid (cf. Text-fig. I).

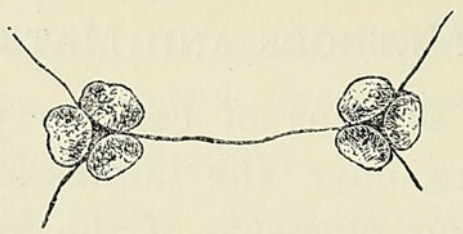

TEXT-FIG. I. Part of a transverse section of Selaginella Wildenovii after treatment with Schulze's maceration fluid and $\mathrm{H}_{2} \mathrm{SO}_{4}$, showing the primary wall and the patches of lignified substance.

A further microchemical test giving uniformly good results was used. Thin sections of Marattia spp. and Gleichenia circinata were stained with methylene blue, the lignified walls of the xylem elements taking on a bright blue colour. Between the lignified bars was a substance which stained violet-blue, this indicating its pectic character (Stevens, 15). On mounting in glycerine the violet-blue of the middle substance faded rapidly, while the bright blue of the lignified parts remained unchanged. The decolorization in glycerine is a further characteristic of pectic substances when stained with methylene blue (Mangin, 7-9).

Following Mangin's method, thin sections of Selaginella Wildenovii were treated for twenty-four hours with acid-alcohol (one part of acid to five of alcohol), then thoroughly washed with distilled water, and stained with methylene blue. In this case also the primary parts were differentiated (Mangin, 7-9).

It will thus be seen that the microchemical evidence for the presence of a primary membrane is decidedly convincing.

\section{Physical Methods of Testing the Nature of the Xylem Elements.}

The methods used by Halft were not repeated, but one of his experiments was utilized in a somewhat modified form.

Portions of the petioles of Marattia spp., Angiopteris evecta, and several polypodiaceous types, and also pieces of the stems of Selaginella Wildenovii and Psilotum triquetrum, were injected (by means of an air-pump) with water containing in suspension a considerable amount of finely ground 
vermilion or Indian ink. Longitudinal sections of the injected stems showed that the granules of colouring matter rose to different heights throughout the xylem, and that they were crowded together in the ends of the pointed elements. It was also noted, both in transverse and longitudinal section, that one element might show granules, while its neighbours were quite free from them (cf. Text-fig. $2(a)$ and $(b)$ ).
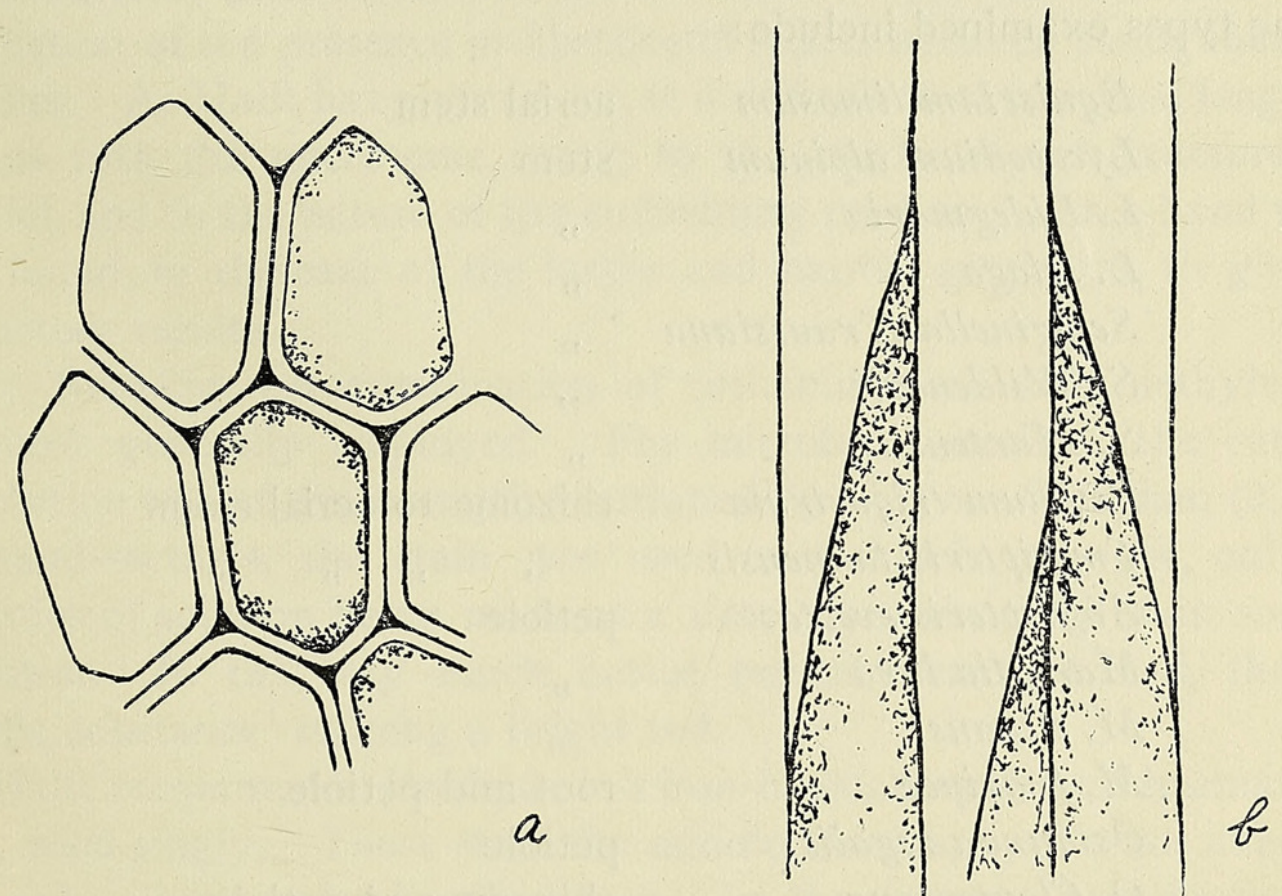

TExT-FIG. 2. (a) Diagrammatic transverse section of the xylem elements of Marattia laxa, illustrating the presence or absence, at the same level, of injected matter adhering to the inner surface of the cell-wall. (b) Diagrammatic longitudinal section of $M$. laxa, showing the accumulation of granules in the pointed ends of the elements.

If the xylem had been a communicating system, as Gwynne-Vaughan states, the granules of cinnabar or Indian ink would have been drawn to the same height throughout, not being impeded by either end or side walls. Again, if the xylem had consisted of true vessels, there would have been no great amount of accumulation of colouring matter in the pointed ends of the elements, for the perforations would have allowed of their passage. But the fact of the presence of injected matter in some, and of its absence in others, of neighbouring elements at the same level, points to the presence of a membrane closing the pits of the lateral walls. Hence it would appear that the xylem of Pteridophyta cannot be a communicating system of the type described by Gwynne-Vaughan; neither can it consist of vessels (at least in the majority of known cases), for the accumulation of granules at the pointed ends of elements shows that the end walls must have acted as filters, not permitting the passage of suspended matter. This points to the presence of a pit-closing membrane here, as well as in the truly lateral portions of the walls; so that the above-described physical tests strongly 
750 Bancroft.-On the Xylem Elements of the Pteridophyta.

support Halft's views as to the tracheidal nature of the xylem elements of the Pteridophyta in general.

III. Microscopical Examination of Material.

I. Material was chosen with a view to extending observations to the lower Filicales, Marattiales, Psilotales, and to other members of those groups representatives of which have already been investigated by Halft.

The types examined include:-

Equisetum limosum

Lycopodium alpinum

L. Phlegmaria

L. selago

Selaginella Kraussiana

S. Wildenovii

S. Martensii

Psilotum triquetrum

Tmesipteris tannensis

Angiopteris evecta

Marattia laxa

$M$. elegans

$M$. fraxinea

Osmunda regalis

O. Claytoniana

O. cinnamomea

Todea hymenophylloides

Lygodium scandens

L. dichotomum

Aneimia fraxinifolia

Mohria caffrorum

Gleichenia circinata

Matonia pectinata

Trichomanes radicans

Polystichum angulare

Blechnum brasiliense

Allosorus crispus

Asplenium bulbiferum

Phlebodium glaucum

Marsilia Drummondii

aerial stem

stem

"

"

"

"

"

rhizome to aerial stem.

petiole

"

"

root and petiole

petiole

rhizome and petiole

rhizome

rhizome and petiole

petiole

,"

"

,

,"

rhizome

rhizome and petiole

petiole

,

rhizome and petiole

rhizome

,

2. Fixing.-The different solutions used for fixing the material were :-

Alcohol (93\% or $95 \%)$.

Farmer's fluid (acid-alcohol).

Jeffrey's solution. 
3. Embedding.-For microtoming, small pieces of material from which all hard cortical layers had been removed were dehydrated, cleared in cedar-wood oil, and embedded in paraffin (M. P. $49^{\circ}-51^{\circ}$ ).

4. Sectioning.-The microtome-sections used were mostly 6 or $8 \mu$ in thickness. In the majority of cases both longitudinal and transverse sections were cut. It was recognized that a comparison of the two was necessary for the satisfactory demonstration of the middle lamella, and also for the explanation of the presence or absence of spaces between contiguous xylem elements. As Halft has pointed out, it is difficult to obtain good longitudinal sections with the microtome, owing to the hardness and structure of the material, and to the nature of the embedding medium. Free-hand sections were found, in the case of the larger and harder specimens, to give more satisfactory results.

5. Staining.-A combination of ruthenium red and methylene blue was most generally employed. For microtome-sections, the ruthenium red solution was of the strength mentioned by Gwynne-Vaughan (2, p. 519). For hand-sections, the stain was used very much stronger, only small quantities of solution being made at a time, since the fluid stain soon loses its power. In this way much better results were obtained, the pectic ' middle substance' staining a bright red.

Halft recommends Haidenhain's iron-haematoxylin and haematoxylinalum, used singly. These stain the middle lamella, but do not affect, or at least only slightly, the lignified bars. In the present investigations both these stains were used with good results. ${ }^{1}$

Other stains found to be effective were Bismarck brown and methyl green; aniline blue and carthamine; Delafield's haematoxylin and safranin ; the first named in each case differentiating the primary substances.

A microscopical examination of sections, prepared as described, affords conclusive evidence as to the accuracy of the inferences drawn from microchemical and physical tests respectively, and demonstrates that the xylem of Pteridophyta is typically composed of tracheides, the middle lamella and pit-membranes remaining in both end and side walls.

\section{Discussion.}

Comparing the views of the two most recent writers on the subject of the Pteridophyte xylem elements, it will be seen how entirely conflicting they are :-

Halft holds that the pit-membranes remain; Gwynne-Vaughan, that they disappear, the pits being actual perforations.

1 Zimmermann (Botanical Microtechnique, 1893, p. 142) notes that haematoxylin is most satisfactory for the recognition of the closing membrane of bordered pits. He used principally Böhmer's solution. 
Halft finds true tracheides; Gwynne-Vaughan finds true vessels, often of a peculiar type.

Halft's observations point to the retention of the primary wall between the transverse bars of lignified substance--those of Gwynne-Vaughan to its retention in elements of the type presented by Pteris Aquilina; to its partial disappearance in multiseriately pitted types of element such as those of Osmunda cinnamomea ; and to its complete disappearance (except, of course, at the angles of the cells) in uniseriately pitted forms, as found in Nephrodium Filix-mas.

As mentioned in the Introduction, Gwynne-Vaughan was led to his conclusions by observations made in connexion with the fossil Osmundaceae. Transverse sections of Osmundites skidegatensis showed apparently clear splits between contiguous xylem elements (cf. 2, Pl. XXVIII, Fig. 2). In the present investigations it was found that sections must be examined under a high magnification (550-1500 diameters), and that they must be fairly thin, if the middle lamella and its continuation as pit-membrane were to be seen distinctly. For example, in a transverse section of Matonia pectinata stained lightly with ruthenium red and methylene blue, the middle lamella was at first overlooked, under a magnification of 325 diameters, though a higher power revealed its presence. But the ordinary fossil section is not prepared for examination under a very high power, and extremely minute histological points may easily be overlooked. Miss Kershaw mentions and figures the occurrence of spaces between the xylem elements in Solenostelopteris (4, p. 686, P1. LVIII, Fig. 5); and an examination of transverse sections of the fossil plants Botryopteris sp., Psaronius sp., Lepidodendron Harcourtii, L. vasculare, Lepidophloios fuliginosus, Sphenophyllum phurifoliatum, and others, proved the frequent occurrence of these apparently clear spaces. It seems, however, unlikely that this appearance is due to the fact that the lamella has disappeared (at least normally-it may be broken down by the attacks of Fungi (cf. Seward, 12)). It is more probable that the means of preparation and examination are, as a rule, not perfect enough to demonstrate its presence, in the case of fossil specimens, especially since its occurrence has been definitely proved in allied types among recent plants, e.g. in members of the Ophioglossaceae, Osmundaceae, and Hymenophyllaceae (cf. Seward, 13 ; Kidston and Gwynne-Vaughan, 5 and 6 ); the Marattiaceae; the Lycopodiales; and the Psilotales.

In the xylem of the Lepidodendreae, fine connexions are often present between adjacent bars of secondary lignified substance, as, for example, in the short elements in the central part of the protostele of Lepidodendron vasculare (Seward, 13). Professor Seward, in describing these delicate connexions, refers to Gwynne-Vaughan's view and remarks that ' in the Lepidodendron tracheae we seem to have a stage in which the intervening membrane is in process of absorption. It is, however, possible that the threads 
may be the result of contraction and splitting of the membrane during drying or decay.' In view of later work it would seem that Professor Seward's second suggestion is the more probable explanation of the apparent connexions.

An examination of a fairly representative collection of fossil slides resulted in the discovery of two excellent longitudinal sections-one of Stigmaria ficoides and one of Sphenophyllum plurifoliatum-showing the middle lamella distinctly (Text-fig. $3, a$ and $b$ ).
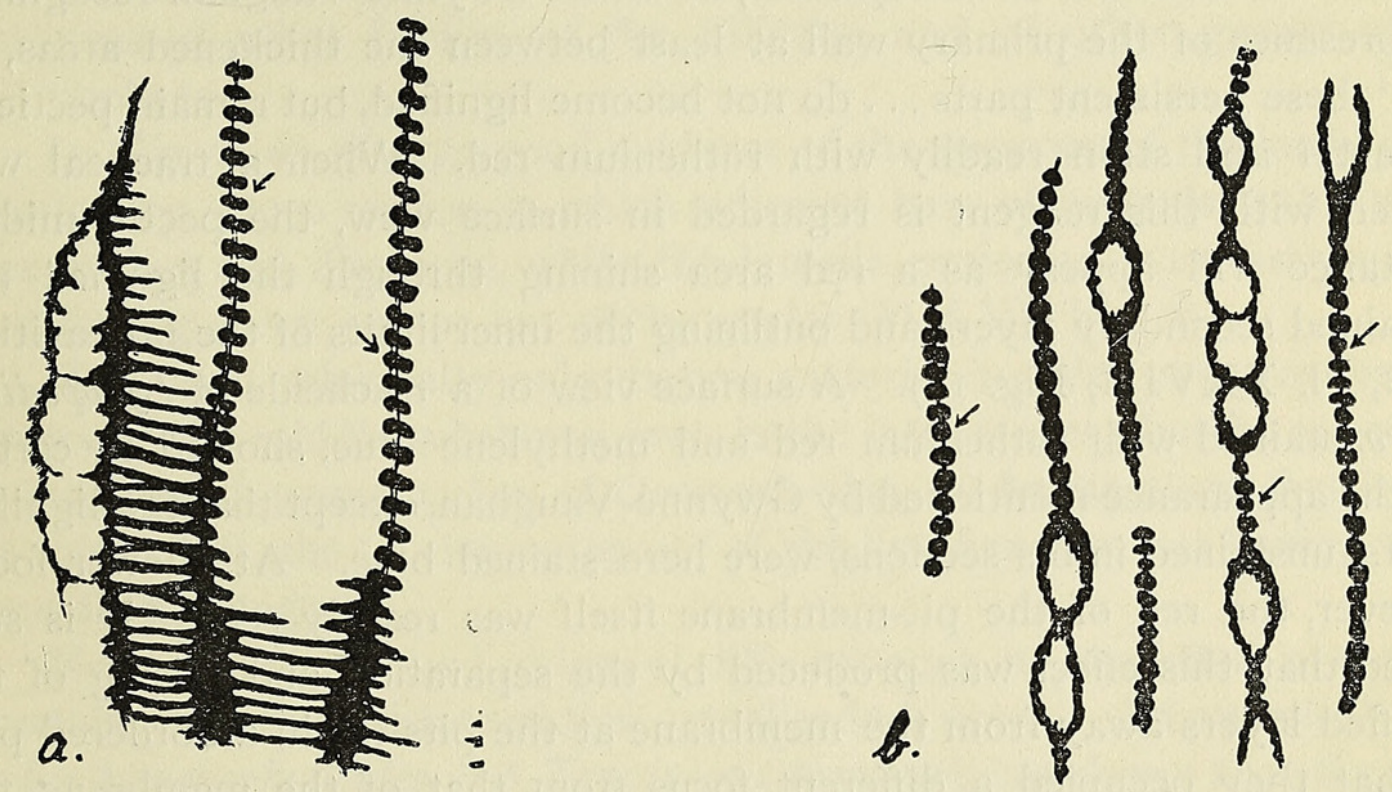

Text-FIG. 3. (a) Stigmaria ficoides. Longitudinal section of xylem. (From a photograph.) (b) Sphenophyllum plurifoliatum. Longitudinal section of xylem. (From a photograph.) (The arrows in both cases point to the middle lamella.)

In S. ficoides the lamella appears as a double line. This is probably due to the fact that the two edges of a thick section are seen, the section being also somewhat oblique, as shown by the bars, and the fact that one line, representing one edge of the arc of lamella, is at a lower focus than the other. ${ }^{1}$

To return to the recent forms, in a fair number of cases longitudinal hand-sections were obtained in which it was clear that a series of scalariform bars must have been cut through twice. But the sections of the bars did not fall away from one another, as would have been the case if GwynneVaughan's view of the absence of a connecting membrane were correct. In fact, it would have been impossible to obtain such a section by hand as that shown in Pl. LVI, Fig. 4.

1 Since the above was sent to press, the writer finds that Williamson and Scott figured the middle lamella in Calamites in their paper 'Further Observations on the Structure of the Fossil Plants of the Coal Measures,' Part I, p. 883, Pl. 78, Fig. 9 (Phil. Trans. B., vol. clxxxv, I894). 


\section{Bancroft.-On the Xylem Elements of the Pteridophyta.}

It would therefore appear that there must be some connexion between the bars, holding them in position, and a high magnification proved this to be the case.

Gwynne-Vaughan considered that where he saw the connecting middle substance between the bars in longitudinal section, he was looking down at the corner of an element where he recognized that the primary parts were retained. This being the case, it is probable that his general reliance upon transverse sections was the cause of his overlooking the presence of a pitclosing membrane.

In the case of Pteris Aquilina, in which Gwynne-Vaughan recognizes the presence of the primary wall at least between the thickened areas, he says ' these persistent parts ... do not become lignified, but remain pectic in character and stain readily with ruthenium red. When a tracheal wall treated with this reagent is regarded in surface view, the pectic middle substance will appear as a red area shining through the lignified and unstained secondary layers and outlining the inner limits of the pit cavities' (cf. 2, Pl. XXVIII, Fig. I0). A surface view of a tracheide of Lycopodium selago, stained with ruthenium red and methylene blue, showed in certain foci the appearance mentioned by Gwynne-Vaughan, except that the lignified layers, unstained in his sections, were here stained blue. At a lower focus, however, the red of the pit-membrane itself was readily seen. It is suggested that this effect was produced by the separation and raising of the lignified layers away from the membrane at the pits (as in a bordered pit), so that they occupied a different focus from that of the membrane, this being, in the actual pit-opening, at too low a focus to be seen. In the areas immediately surrounding the pit-space the primary red-stained pectic layers did not shine through, as here they were not backed and covered closely by the lightly blue-stained parts.

A simple illustration will make this last suggestion more clear. Suppose a piece of red paper to represent the middle primary substance stained with ruthenium red, and two pieces of thin blue paper placed closely, one behind and one in front of it, to represent the layers of secondary thickening stained with methylene blue. If the light is allowed to pass through these three layers, when in contact with one another, the red will be seen through the blue. But if the three layers are separated, as is the case in a pit-area, the red will not shine through the blue so readily.

In his description of the growth and formation of the xylem elements in Osmunda cinnamomea (as typical of the Osmundaceae and of multiseriately pitted forms in general), Gwynne-Vaughan remarks that the pectose primary wall is present in immature elements, and that, as maturity is attained and lignification of the secondary layers becomes fairly strong, it gradually disintegrates, except at the angles and (in this particular type) between the series of pits. This is clearly shown in his Fig. 8. Eventually, 
according to his view, disintegration is complete and an empty space is left between the thickening bars of contiguous elements.

Halft's researches prove, however, that in Osmunda regalis, as well as in other forms, the spaces between the lignified bars are not entirely empty - the middle lamella stretches across from end to end. In this connexion Mr. Sinnott's excellent photographs, illustrating 'Foliar Gaps in the Osmundaceae', may be mentioned. His Fig. 8 (Todea hymenophylloides) shows the presence of the lamella perfectly (Sinnott, 14). The writer has also observed the lamella in Osmunda Claytoniana, O. cinnamomea, and Todea hymenophylloides amongst the Osmundaceae, as well as in representatives of other families of the Filicales and of other groups of the Pteridophyta.

In Gleichenia dicarpa good evidence of the presence of the lamella was afforded by a torn section, in which adjacent bars of secondary thickening were broken and displaced, while the lamella projected from between the bars, having given way at one of the angles (Pl. LVI, Fig. 6).

Halft used principally only mature material in order to prove the persistence of the middle substance, even in the later stages; but he appears to have sectioned young xylem of Osmunda also, for he mentions that it does not show splits, the 'springing apart' of the lignified bars not having taken place at this stage.

Not having sectioned xylem of different ages, he has failed to see that a certain amount of disintegration actually does occur. An examination of Todea hymenophylloides and Tmesipteris tannensis has shown that the splits between the bars of thickening of adjacent elements are formed by the partial disappearance of the primary wall, leaving the middle membrane traversing the space from end to end. Its extreme delicacy renders it difficult of observation, especially if the staining is light and the focus not extremely exact.

Halft appears to think that the presence of a split is due to the mere 'springing apart' of the bars of thickening, and that the primary wall remains between, no dissolution taking place. But the pit-membrane is middle lamella only, and as the primary wall consists of middle lamella and layers of pectic substances on either side, it would seem that some disintegration of the primary wall must occur where the middle lamella is exposed and separated from the secondary bars. Where the bars actually join, it may be supposed that the primary layers remain, as well as the middle lamella. The longitudinal section of Tmesipteris tannensis (Fig. 15) in particular supports this view-the primary layers being distinctly thicker where the bars join than where they separate, thus indicating what the transverse sections showed to be the case-that some disintegration has taken place.

It may be that a certain amount of 'springing apart' helps the widening 
of the splits in some cases, when the bars are no longer held together by the primary wall; but it seems reasonable to maintain that some disintegration precedes the separation, which begins before lignification is very far advanced.

It is further suggested that upon the actual amount of breaking down of the primary wall between corresponding pairs of bars depends the presence or absence of a 'split' as seen in transverse section.

If the disintegration is great, the bars will be connected only for a very small fraction of their whole width, as in Matonia pectinata (Pl. LVI, Fig. 2). The corresponding transverse section (Fig. I) shows the splits wide and clear, and it is obvious that in transverse sections it will be comparatively rarely that the junction of the bars is cut through-hence the general appearance of splits in such a type. If the amount of disintegration is slight, as shown in the longitudinal section of Marattia fraxinea (Fig. 4), the connexion between the bars extends nearly their whole width, and the prevalence of the 'non-split' appearance as seen in transverse section (Fig. 3) is clearly due to the plane of section cutting (in the majority of cases) the regions where the bars are joined. The variation in the width of the splits in different types may be the result of the different amounts of the raising or springing apart of the bars in the pit areas.

It seems unwise to attempt to classify types under the head of 'split' or 'non-split', for between the two extremes illustrated by Matonia and Marattia there may be any number of cases showing intermediate degrees of separation of the thickening bars, representing not only different amounts of disintegration of the primary wall, but also different degrees of springing apart of the secondary layers, the splits being sometimes wide, as in Matonia pectinata (Figs. I and 2) and Lygodium scandens (Fig. II), and sometimes narrow, as in Selaginella Wildenovii (Figs. 7 and 8) and Lygodium dichotomum (Figs. I2 and I3). A transverse section of Aneimiodictyon sp. (petiole) showed a type nearest that of Marattia, though not so extreme, while allies of this species, Aneimia fraxinifolia (Figs. I6 and I7) and Mohria caffrorum, presented a type almost as extreme as Marattia. Psilotum triquetrum (Figs. 9 and 10) and Tmesipteris tannensis (Figs. I4 and I5) showed fairly wide splits on the whole, though the relative width of these seemed to vary in different parts of the plant. In the species of Osmunda examined, the xylem of the rhizome was found to have large splits, while that of the petioles exhibited the opposite extreme. This being the case, it is hardly surprising that there is little constancy of type among species of the same genus or family, though Marattia laxa, $M$. fraxinea, M. elegans, Angiopteris evecta, and Danaea sp. (cf. Figs. 3, 4, and 5) were found to approximate to the same type.

Where the connexion between successive pairs of thickening bars is narrow it is clear that the mechanical efficiency of the xylem elements will 
be much less than where the connexion of the bars is wider. It is tentatively suggested that there may be a mechanical explanation of the variation in type. In the case of Osmunda, for example, where there is variation within the organs of the same plant, the mechanical needs are clearly greater in the petiole than in the rhizome, and the efficiency of the xylem as a strengthening tissue is here raised by the wider connexions of the bars.

Again, where the connexion of the thickening bars is slight, there will be a larger area through which transfusion of water and solutions may take place, in a lateral direction as well as vertically.

The different parts of the conducting system in this case will be in more facile communication than where the exposed areas of lamella are smaller and transfusion is consequently somewhat retarded.

With regard to the detection of true vessels, ${ }^{1}$ such as were found by Halft in Pteris Aquilina, longitudinal sections are necessary, for it seems that the perforation of the end walls of the xylem elements depends, in a great measure at least, upon the amount of their inclination, and that where end and side walls grade into one another and are not properly differentiated, as is the case in the pointed elements of Osmunda regalis, pit-membranes remain throughout; but where end walls are well defined and very little inclined to the lateral walls, the need for true perforations may arise. In all the cases where longitudinal sections were used as controls to the transverse (as in the majority of the types mentioned), true pointed tracheides were found, confirming the opinion of Halft that these are the rule in Vascular Cryptogams.

\section{SUMMARY.}

I. The xylem elements of Pteridophyta are typically pointed tracheides, the pits on both end and side walls being closed by a membrane formed by the persistent middle lamella.

2. The middle lamella is believed to be exposed in the pit areas by the disintegration of the rest of the primary wall.

3. The varying amounts of disintegration give rise to the prevalence of the 'split' or 'non-split' appearance between the secondary lignified layers, as seen in transverse section.

4. The width of the split depends largely upon the degree of separation of the secondary layers in the areas surrounding the pit openings.

The grateful acknowledgements of the writer are due to Dr. H. C. I. Fraser for drawing attention to this problem; to Professor Carr for material and opportunities for research; and to Professor Gwynne-Vaughan and Mr. H. S. Holden for valuable criticism and advice.

1 Halft employs the term 'trachea' in its limited sense meaning 'vessel', whilst GwynneVaughan apparently follows De Bary's usage, giving it a comprehensive application. In the present instance also, 'trachea' is understood to include both 'vessel ' and 'tracheide'. 


\section{REFERENCES.}

1. De BARY: Vergleichende Anatomie der Vegetationsorgane. Hofmeister, Handbuch der physiol. Bot., Bd. iii, I877.

2. Gwynne-Vaughan, D. T.: On the Real Nature of the Tracheae in the Ferns. Ann. of Bot, vol. $x x i i$, I908, p. $5^{1}$ \%

3. Halft, Fr.: Die Schliesshaut der Hoftüpfel im Xylem der Gefässkryptogamen, IgIo. Dissertation.

4. Kershaw, E. M. : A Fossil Solenostelic Fern. Ann. of Bot., vol. xxiv, ig1o, p. 683 .

5. Kidston, R., and Gwynne-Vaughan, D. T. : On the Fossil Osmundaceae, Pt. I. Trans. Roy. Soc. Edin., vol. xlv, Pt. III, I907, p. 759.

6. $\quad$ Ib., vol, xlvi, Pt. II, I908.

7. Mangin, L. : Sur la présence des composés pectiques dans les végétaux. Bull. de la Soc. bot. de France, t. cix, 1889 , p. 579.

8. - Sur les réactifs colorants des substances fondamentales de la membrane. Ib., t. cxi, 1890 , p. 120.

9. - Sur la substance intercellulaire. Ib., t. cx, p. 295.

10. Russow : Vergleichende Untersuchungen. Mém. de l'Acad. Imp. des Sci. de Saint-Pétersbourg, t. $x i x, 1872$.

11. SAnio: Anatomie der gemeinen Kiefer. Pringsh. Jahrb., Bd. ix, I8 73 .

12. Seward, A. C. : Fossil Plants. Vol. i, I898, pp. 2 I $5^{-16 .}$

13. — Ib., vol. ii, I910, pp. 470-2.

14. Sinnott, E. W.: Foliar Gaps in the Osmundaceae. Ann. of Bot, vol, xxiv, 1910, p. 107.

15. Stevens, Wm. C.: Plant Anatomy. Second ed., 1910, p. 313.

16. Strasburger, E.: Über den Bau und die Vorrichtungen der Leitungsbahnen in den Pflanzen. I 89 I.

17. : Text-book of Botany. Third English ed., 1908, p. 99.

(Further references may be found in the works quoted.)

\section{EXPLANATION OF PLATE LVI.}

Illustrating Miss Bancroft's paper on the Xylem Elements of the Pteridophyta.

(The figures are semi-diagrammatic, the magnification being $I, 500$ diams. in each case).

Fig. I. Matonia pectinata. Transverse section of xylem elements of rhizome, showing the middle lamella traversing wide spaces between them.

Fig. 2. Matonia pectinata. Longitudinal section, showing narrow connexions of the thickening bars.

Fig. 3. Marattia fraxinea. Transverse section of xylem of petiole. The thickening bars are closely connected; no spaces show between them.

Fig. 4. Marattia fraxinea. Longitudinal section through a series of lignified bars. Note the wide connexions between successive pairs. A pointed end of an element is also shown $(a)$.

Fig. 5. Angiopteris evecta. Longitudinal sections. Cf. Fig. 4, showing the same type.

Fig. 6. Gleichenia dicarpa. Transverse section of xylem of rhizome, showing the torn lignified bars and the projecting lamella.

Fig. 7. Selaginella Wildenovii. Transverse section of xylem of stem. The spaces between the bars are relatively narrow. 
Bancroft.-On the Xylem Elements of the Pteridophyta. 759

Fig. 8. Selaginella Wildenovii. Longitudinal section corresponding to the transverse section shown in the previous figure.

Fig. 9. Psilotum triquetrum. Transverse section of xylem of aerial stem-the middle lamella traverses spaces between the elements.

Fig. Io. Psilotum triquetrum. Longitudinal sections, showing the narrow connexions between the lignified layers.

Fig. I I. Lygodium scandens. Transverse section of xylem of twining petiole. Compare the wide splits exhibited by this part of the xylem with those in

Fig. I2. $L$. dichotomum (petiole), where they are relatively much narrower.

Fig. I3. L. dichotomum. Longitudinal section, corresponding to Fig. I 2.

Fig. I4. Tmesipteris tannensis. Transverse section of xylem of aerial stem. The lamella is seen in the spaces between the tracheides.

Fig. I5. Tmesipteris tannensis. Longitudinal section, showing the connexions between the thickening bars.

Fig. 16. Aneimia fraxinifolia. Transverse section of xylem of petiole. No spaces are shown. Cf. Marattia fraxinea.

Fig. I7. Aneimia fraxinifolia. Longitudinal section, corresponding to Fig. I6. 
Annals of Botany,
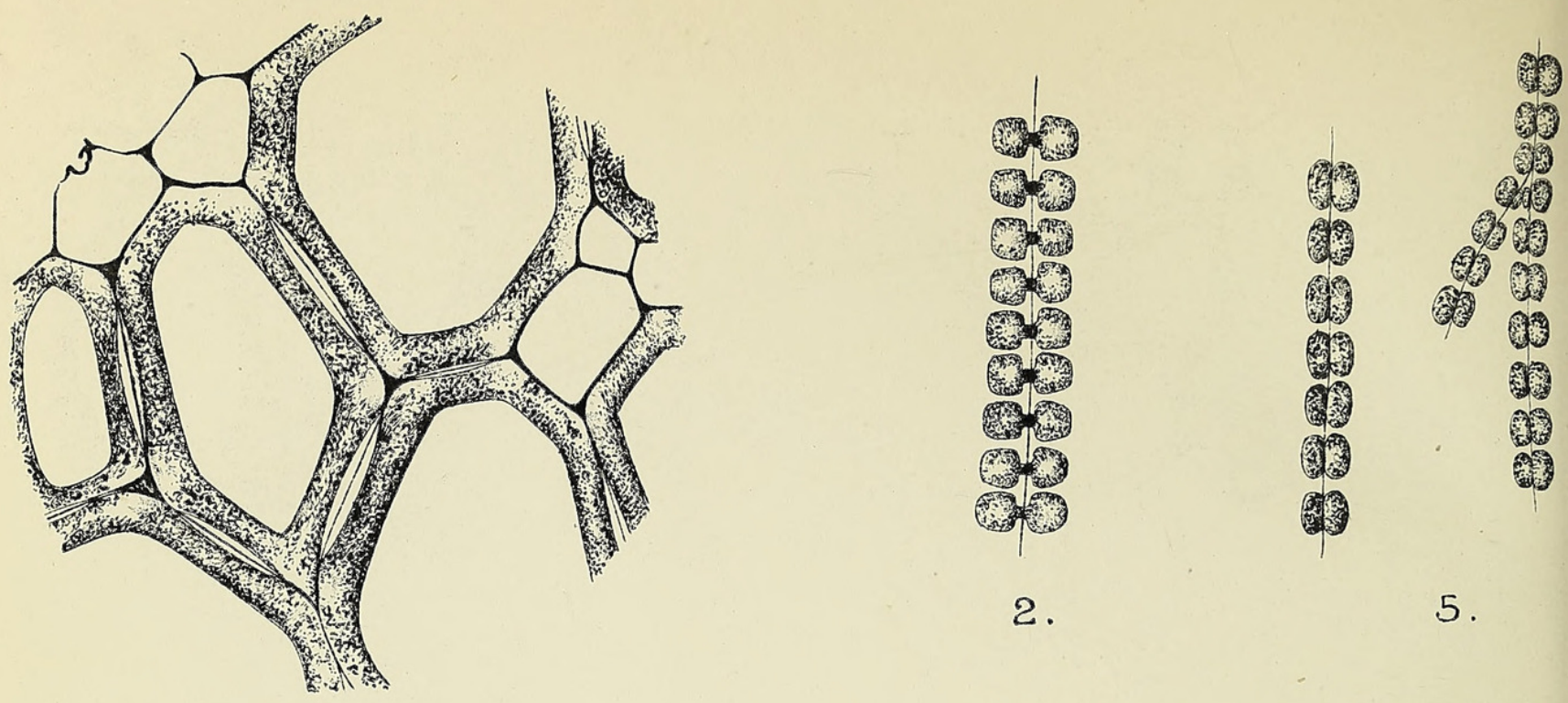

2 .

5.
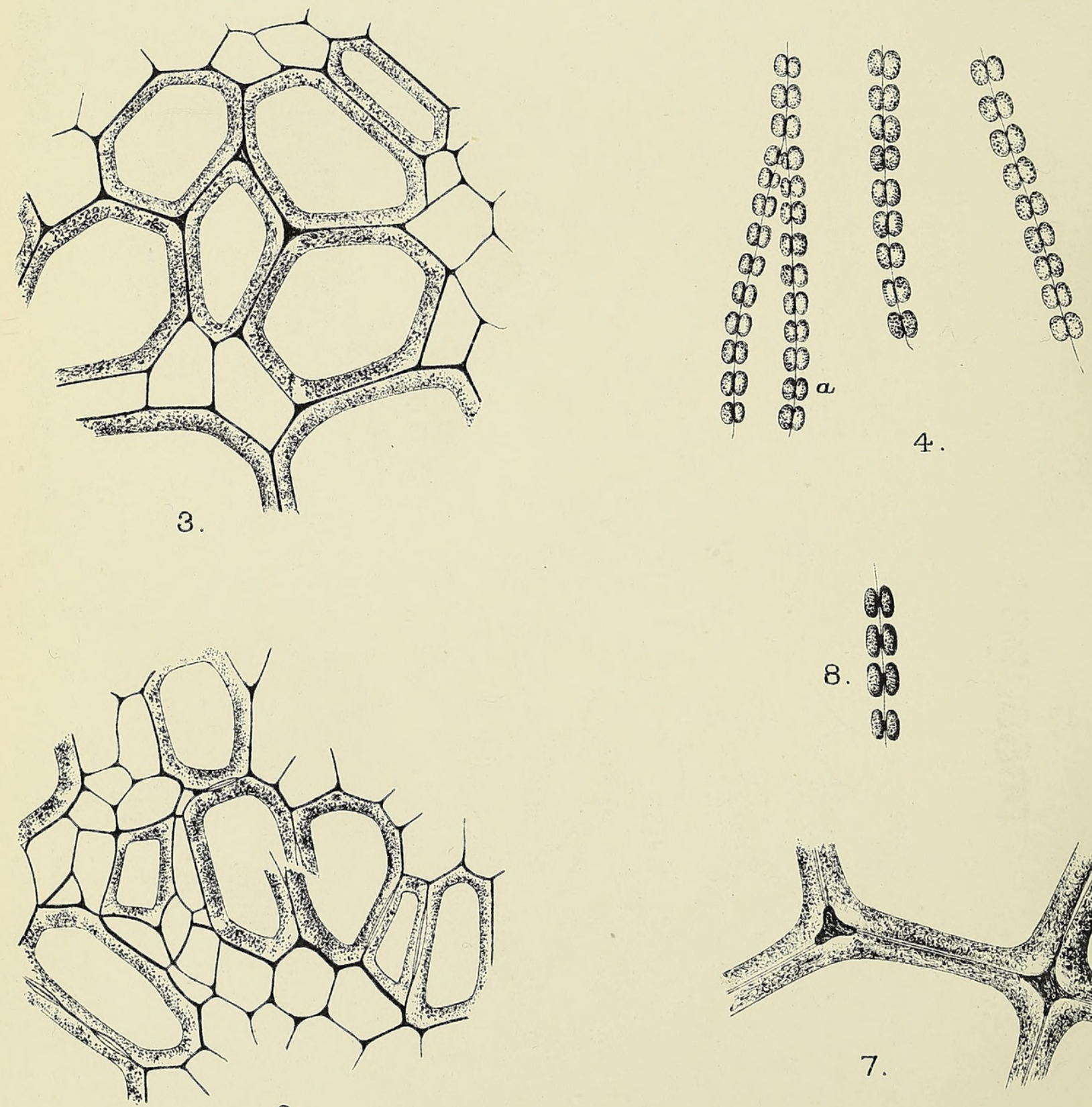

8.

6. 
Vol. XXV. Pl.LIT.
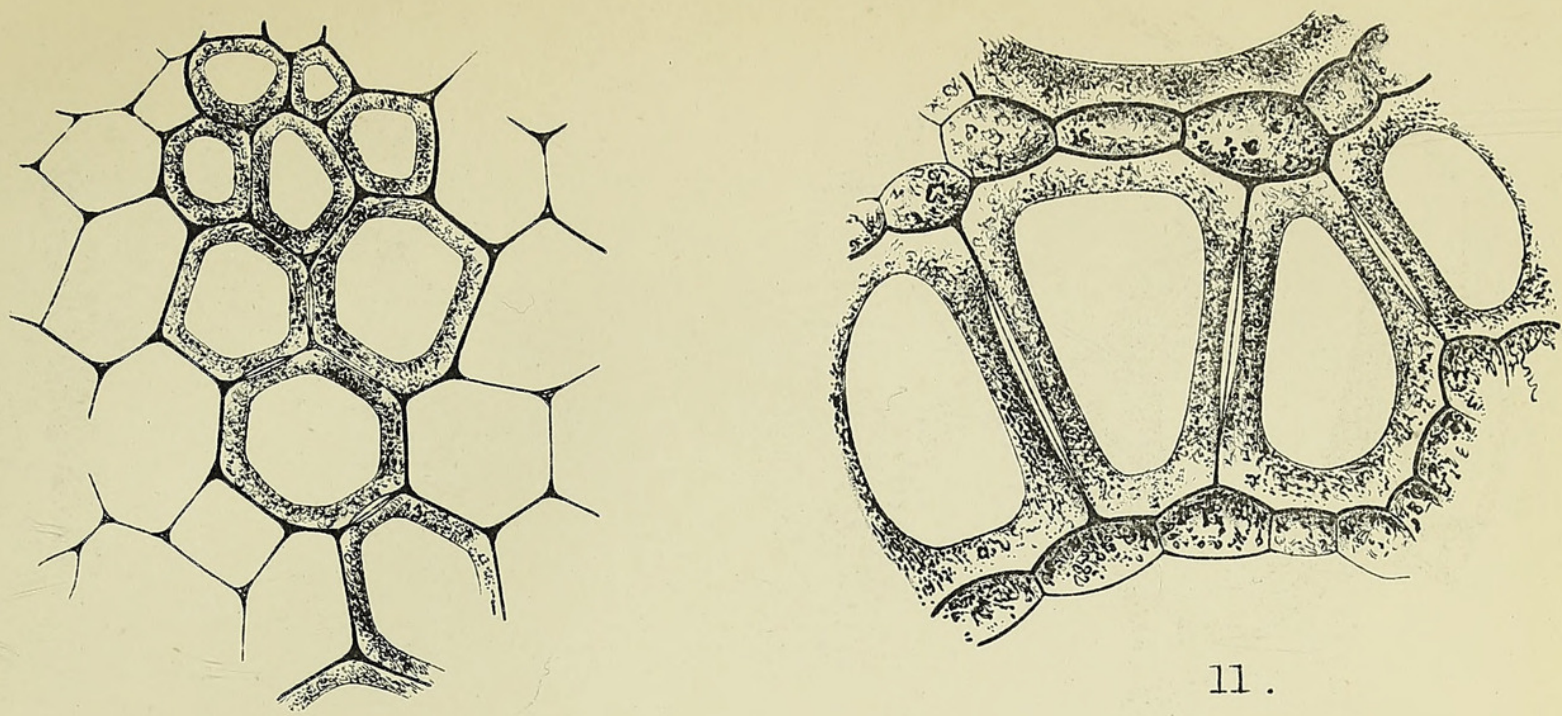

9.

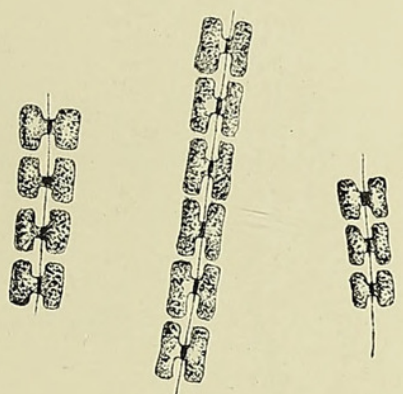

10.

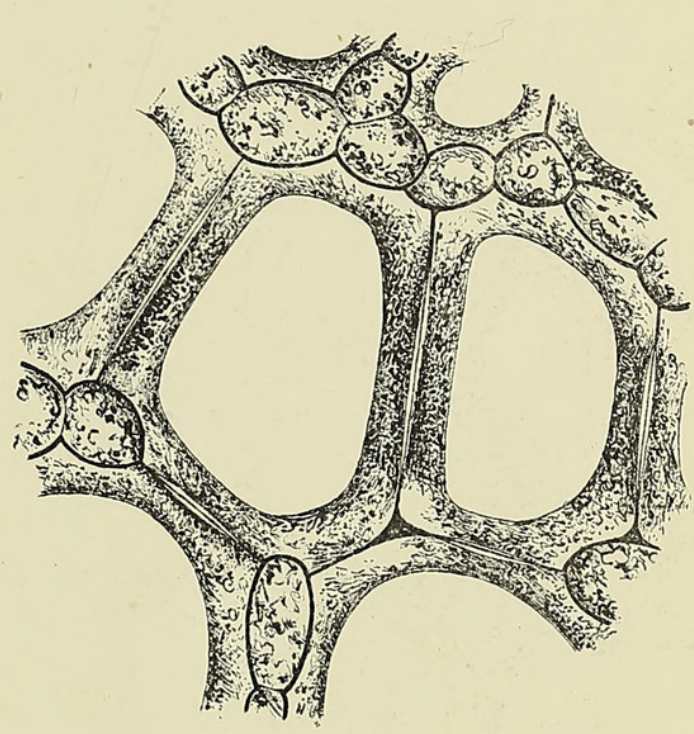

6

0

\%

12.

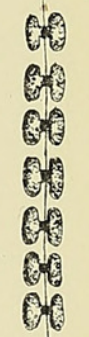

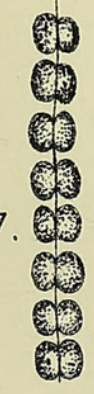
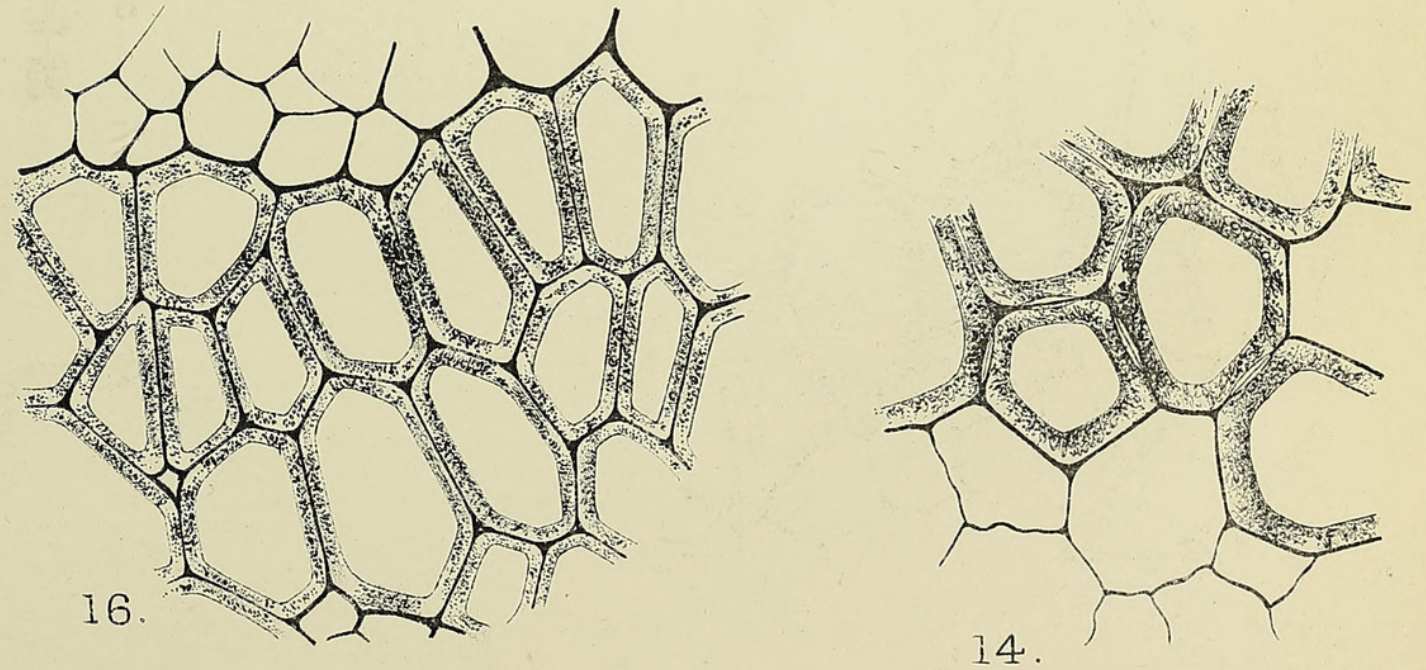


\section{$2 \mathrm{BHL}$ Biodiversity Heritage Library}

Bancroft, Nellie. 1911. "On the xylem elements of the Pteridophyta." Annals of botany 25, 745-759. https://doi.org/10.1093/oxfordjournals.aob.a089351.

View This Item Online: https://www.biodiversitylibrary.org/item/239487

DOI: https://doi.org/10.1093/oxfordjournals.aob.a089351

Permalink: https://www.biodiversitylibrary.org/partpdf/319859

\section{Holding Institution}

Smithsonian Libraries

\section{Sponsored by}

Biodiversity Heritage Library

\section{Copyright \& Reuse}

Copyright Status: Not in copyright. The BHL knows of no copyright restrictions on this item.

This document was created from content at the Biodiversity Heritage Library, the world's largest open access digital library for biodiversity literature and archives. Visit BHL at https://www.biodiversitylibrary.org. 